\title{
BILDIRCIN NUGGET ÜRETİMİ VE DEPOLAMA STABİLİTESİNINN BELİRLENMESİ
}

\author{
Levent Gülüm ${ }^{1}$, İlker Turan Akoğlu ${ }^{2}$, Aylin Akoğlu ${ }^{3, *}$ \\ 1) Bolu Abant İzzet Baysal Üniversitesi, Mudurnu Süreyya Astarcı Meslek Yüksekokulu, Bitkisel ve Hayvansal \\ Üretim Bölümü, Bolu, Türkiye \\ 2) Bolu Abant İzzet Baysal Üniversitesi, Mühendislik Fakültesi, Gıda Mühendisliği Bölümü, Bolu, Türkiye \\ 3) Bolu Abant İzzet Baysal Üniversitesi, Sağlık Bilimleri Fakültesi, Beslenme ve Diyetetik Bölümü, Bolu, Türkiye \\ Geliş / Received: 10.05.2019; Kabul / Accepted: 06.09.2019; Online bask1 / Published online: 11.10.2019
}

Gülüm, L., Akoğlu, İ. T., Akoğlu, A. (2019). Bildırcın nugget üretimi ve depolama stabilitesinin belirlenmesi. GIDA (2019) 44 (6): 954-968 doi: 10.15237/gida.GD19077

Gülüm, L., Akoğlu, İ. T., Akoğhu, A. (2019). Quail meat nugget production and determination of storage stability. GIDA (2019) 44 (6): 954-968 doi: 10.15237/gida.GD19077

\section{ÖZ}

Bu çalıșmada bıldırcın nugget üretimi ve depolama stabilitesinin belirlenmesi amaçlanmıștır. Calıșmada \%75 bıldırcın eti ve $\% 25$ piliç eti kullanılarak nuggetlar (BN) üretilmiş, ardından $4^{\circ} \mathrm{C}$ ve $-18^{\circ} \mathrm{C}$ 'de depolanarak kimyasal, mikrobiyolojik ve duyusal analizleri gerçekleştirilmiştir. Yapılan analizlerde BN örneklerinin su, yağ, protein ve kül içeriği sırasıyla, \%55.97, \%8.84, \%16.17 ve \%2.08 olarak tespit edilmiştir. Yağ asitleri bileşimine bakıldığında, en yüksek orana sahip yağ asitleri linoleik asit (\%21.55), linolenik asit (\%21.78) ve palmitik asit (\%19.18) olarak belirlenmiş̧tir. Soğuk depolamada kimyasal analizlerden $\mathrm{pH}$, peroksit, sertlik-2, sakızımsılık, sıkılık; duyusal analiz parametrelerinde ise diş renk ve koku değerlerindeki değişiklikler istatistik açıdan önemli bulunmuştur $(P<0.05)$. Donmuş depolamada ise su aktivitesi, peroksit, sertlik-2, sakızımsıllk, elastikiyet, çiğnenebilirlik, esneklik, sertlik-1 ve sikılık değerlerindeki değişimlerin istatistik olarak önemli olduğu tespit edilmiştir $(P<0.05) .4^{\circ} \mathrm{C}^{\prime}$ deki 20 günlük depolama sonunda TMAB, TPAB ve toplam Enterobacteriaceae saylları sirasiyla 5.70 $\pm 0.3,6.40 \pm 0.1 \mathrm{ve}<1 \mathrm{log} \mathrm{kob} / \mathrm{g}$ olarak bulunmuş, Salmonella spp. ve Listeria monocytogenes ise tespit edilmemiştir.

Anahtar kelimeler: Kanatlı eti, bildırcin eti, nugget, üretim, depolama

\section{QUAIL MEAT NUGGET PRODUCTION AND DETERMINATION OF STORAGE STABILITY}

\begin{abstract}
In this study it was aimed to produce quail nugget and to determine its storage stability. Nugget samples consisting of $75 \%$ quail meat and $25 \%$ chicken meat were produced and stored at $4{ }^{\circ} \mathrm{C}$ and $-18^{\circ} \mathrm{C}$ and physicochemical, microbiological and sensory analyzes were performed. In the analyzes, the moisture, fat, protein and ash content of BN samples were determined as $55.97 \%, 8.84 \%, 16.17 \%$ and $2.08 \%$ respectively. In the composition of fatty acids, the highest fatty acids were determined as linoleic acid $(21.55 \%)$, linolenic acid $(21.78 \%)$ and palmitic acid (19.18\%). In cold storage, $\mathrm{pH}$, peroxide, hardness -2 , gum, tightness values in the chemical analysis; the external color and odor values in the sensory analysis were found to be statistically significant $(P<0.05)$. In frozen storage, water activity, peroxide, hardness2 , gum, elasticity, chewiness, elasticity, hardness-1 and tightness values were found to be statistically significant $(P<0.05)$. At the end of 20 days storage at $4^{\circ} \mathrm{C}$, TMAB, TPAB and total Enterobacteriaceae numbers were found to be $5.70 \pm 0.3,6.40 \pm 0.1$ and $<1 \mathrm{log} \mathrm{cfu} / \mathrm{g}$, respectively, and Salmonella spp. and Listeria monocytogenes were not detected.
\end{abstract}

Keywords: Poultry meat, quail meat, nugget, production, storage

\section{*Yazışmalardan sorumlu yazar/ Corresponding author}

$\triangle$ aylinakoglu@ibu.edu.tr @ (+90) 374254 1000/4780 圆 (+90) 3742534557 


\section{GİRİ̧̧}

"Kanatlı hayvan" terimi; ticari ya da hobi amaçlı olarak yetiştiriciliği yapılabilen tavuk, hindi, kaz, ördek, bıldırcın, sülün, keklik, deve kuşu, beç tavuğu ve güvercin gibi çok çeşitli kanatlı türlerini kapsamaktadır. Kanatlı hayvan yetiştiriciliği, dünyada üzerinde önemle durulan bir hayvansal üretim dalıdır (Akgün, 2006). Kanatlı hayvanlar, çıkımdan itibaren kısa sürede (40-45 gün) kesim olgunluğuna gelmeleri, her bölgeye uyum sağlamaları, karkas randımanlarının yüksek olması, üretim masraflarının düşük olması, jenerasyon sürelerinin k1sa olmas1, et veriminin artırılmasına yönelik bilimsel çalışmalara hızla cevap verebilmeleri, civciv olarak kolay ve ucuza temin edilebilmeleri, her türlü yemi değerlendirebilmeleri ve bunların yanında; hazırlanma süresinin ve servisinin kolay olmas1, elzem besin öğelerinin birçoğuna sahip olması ve duyusal özelliklerinin iyi olması nedenleriyle tercih edilmektedir (Anıl vd., 1995; Ergezer, 2005). Bu bağlamda kanatlı ürünleri, hem dünyada hem de ülkemizde ekonomik hayvansal protein kaynağını oluşturarak sürekli büyüme ve gelişme göstermektedir. Kanatlllar arasinda önemli bir tür olan bıldırcınların üretimi ise hızlı bir şekilde artış göstermektedir (Maiorano vd., 2011; Şekeroğlu vd., 2013; Yıldırım ve Öztürk, 2013). Bildırcın, piliçlere oranla; yetiştirilmesi için gerekli alanın daha düşük olması (Sarıca vd., 2003), daha az yem tüketiminin olması (Nazlıgül ve Bardakçıŏglu, 2001; Laçin vd., 2007), çok kısa bir sürede eşeysel olgunluğa erişmesi ve jenerasyon aralı̆̆ının daha kısa olması (İnal, 2013; Çelik vd., 2014), hastalıklara ve ekstrem koşullara daha dayanıklı olması (Çelik vd., 2014) gibi bir takım avantajlara sahiptir. Bu özelliklerden dolayı, bıldırcin yetiştiriciliği piliç ve ördeğe kıyasla neredeyse aynı kâr marjına kıyasla çok daha düşük sermaye yatırımına ihtiyaç duymakta ve içerdiği zengin kaynaklar sayesinde üretiminin gerçekleştirilmesi gerektiği vurgulanmaktadır (Nasar vd., 2016). Bıldırcın etinin lezzetli olması ve besleyicilik değerinden dolayı diyet programlarına uygunluğu, tüketicinin bu ürüne olan ilgisini artırmaktadır (Genchev vd., 2008). Bildırcin, et kalitesi açısından (pH, renk ve doku), piliç etine benzemektedir. Ayrıca derisinde çok az yağ ve kolesterol içermesi nedeniyle de düşük kolesterolünü korumak isteyen tüketiciler için ideal bir gidadır (Nasar vd., 2016).

Ülke ekonomisi için stratejik bir öneme sahip olan kanatlı etleri ve ürünlerinin tüketimini artırmak amacıyla ürün çeşitliliğinin artırılması gerektiği öngörülmüş, et ve et ürünleri içerisinde ise kaplamalı ürünlerin tüketiminde artış eğiliminin olduğu belirtilmiştir. Tüketiciler için elde edilen ürünlerin damak zevkine hitap etmesinin yanında beslenme trendlerine de ayak uydurması açısından nugget, önemli bir çeşidi oluşturmaktadır (Güner, 2005). Bıldırcın, hâlihazırda birçok işletme tarafindan yumurta üretimi için yetiştirilmekte ve piyasada bulunan bıldırcın etinin ise sadece bütün bıldırcın eti olarak satıldığ1 görülmektedir. Bıldırcının kaplamalı ürünler için kullanılan bir hammadde olmasi durumunda bu alanda talep edilen diğer gidalar içerisine girebileceği düşünülmektedir.

$\mathrm{Bu}$ çalışmada bıldırcın ve piliç etlerinin farklı oranlarda karıştırılması ile üretilen nuggetın, tüketime elverişliliğinin belirlenmesi ve bıldırcın etinin et ve et ürünleri sektörüne kazandırılması amaçlanmıstır. $\mathrm{Bu}$ amaçla üretilen nuggetlar, soğuk ortamda ve dondurularak muhafaza edilmiş ve depolanmaları sürecinde kimyasal, mikrobiyolojik ve duyusal analizler yapilarak kalite değişimleri belirlenmiştir.

\section{MATERYAL VE YÖNTEM}

\section{Materyal}

Çalışmada materyal olarak Bolu Abant İzzet Baysal Üniversitesi, Ziraat ve Doğa Bilimleri Fakültesi, Kanatlı Hayvan Yetiştiriciliği Bölümü bünyesinde yetiştirilen Japon bıldırcınlarının but ve göğüs etlerinin karışımından elde edilen kıyma kullanılmıştır. Nugget üretiminde Erpiliç A.Ş.'de ticari piliç nugget üretimi için kullanılan piliç yağı, bitkisel sıv1 yağ, bitkisel lifler (bambu, bezelye, buğday), tuz, baharat, stabilizör (sodyum polifosfat), ekmek mayası ve renk maddeleri (annatto, kurkumin) gida katk1 maddeleri kullanılmıştır.

\section{Yöntem}

Farkl1 formulasyonlarda hazirlanan nuggetlar (bıldırcın ve piliç eti karışımı) eğitimli panelistler 
tarafindan duyusal analize tabi tutulmuş ve asıl denemelerde kullanilacak olan nugget formülasyonu belirlenmiştir (Gülüm vd. 2016). Buna göre en beğenilen formülasyon olan $\% 75$ bıldırcın eti- $\% 25$ piliç eti kullanılarak nugget üretimi Erpiliç A.Ş.'nin İleri İşlenmiş Ürünler Bölümü’nde (Göynük-Bolu) gerçekleştirilmiştir. Aynı şekilde kontrol örneği olarak kullanılmak üzere $\% 100$ piliç etinden oluşan nugget üretimi de gerçekleştirilmiştir. Nuggetlar için firmanın verdiği raf ömürlerine istinaden; soğuk $\left(4^{\circ} \mathrm{C}\right)$ depolama şartlarında $0 ., 5 ., 10 ., 15$. ve 20. günlerde; donmuş $\left(-18^{\circ} \mathrm{C}\right)$ depolama şartlarında ise 30., 60., 90., 120. günlerde fizikokimyasal, duyusal ve mikrobiyolojik analizler gerçekleştirilmiştir.

\section{Kimyasal Analizler}

$\mathrm{pH}$, su, protein, yağ, kül içeriği ölçümleri AOAC (1990)'a göre gerçekleştirilmiştir. Üründeki oksidatif bozulmaların belirlenmesi için yapılacak olan peroksit ve serbest yağ asitliği (SYA) analizlerinde kullanılmak amaciyla soğuk ekstraksiyonla üründeki yağ elde edilmiştir (Bligh ve Dyer, 1959) ve ardından elde edilen yağ örneklerinden peroksit (AOCS, 2003) ve SYA değerleri (AOAC, 1990) belirlenmiştir. Örnekte bulunan yağ asitlerinin tanımlanmasında 37 yağ asidi metil esteri karışımından oluşan standart kullanılmıştır (Jimenez vd., 2006). Nugget örneklerindeki lipit oksidasyonunun düzeyi, tiyobarbitürik asit (TBA) değeri analizi ile belirlenmiş̧tir (Tarladgis vd., 1960). Nugget örneklerindeki su aktivitesi değerleri $\left(a_{w}\right)$, AW LAB RTD-502 marka tayin cihazıyla ölçülmüştür (Ensoy, 2004; Çolak vd., 2011). Nugget örneklerinin kesit yüzeyi renk yoğunlukları, örneklerin yüzeyinden rastgele seçilen 3 farklı noktadan ölçüm yapılarak Minolta Chromameter CR300 kolorimetre cihaz1 kullanilarak belirlenmiştir (Hunt vd., 1991).

\section{Tekstür Analizi}

Nugget örneklerinde tekstür analizi, kesme analizi ve tekstür profili analizi (TPA) olmak üzere TA.HD. Plus Stable Micro Systems cihazı kullanılarak yapılmıştır. Pişmiş ürünler uygun bir tabla üzerine alınıp kesme analizi için $1.5 \mathrm{~cm} \times 0.8$ $\mathrm{cm} \times 5 \mathrm{~cm}$ (genişlik $\mathrm{x}$ yükseklik $\mathrm{x}$ uzunluk) boyutlarında; tekstür profili analizi (TPA) için ise $1.5 \mathrm{~cm} \times 0.8 \mathrm{~cm} \times 1.5 \mathrm{~cm}$ (genişlik x yükseklik x uzunluk) boyutlarında kesilmiştir. Kesme analizinde Warner Bratzler Shear bıçağı kullanılmıştır. Analizde test öncesi hız $2 \mathrm{~mm} / \mathrm{s}$, test hizı $2 \mathrm{~mm} / \mathrm{s}$, test sonrası hız $10 \mathrm{~mm} / \mathrm{s}$ olacak şekilde 5 kg'llk yük hücresi kullanılarak, 20 g'llk tetikleyici kuvvetle, bıçak ete değdikten sonra 3 $\mathrm{cm}$ kesme yapılmıştır. Her bir örneğin farklı noktalarından iki kesme yapılarak sıkılık ve sertlik1 değerleri saptanmıştır. TPA'da ise TPA P/100 probu kullanılmıştır. Analizde test öncesi hız 2 $\mathrm{mm} / \mathrm{s}$, test hizi $0.5 \mathrm{~mm} / \mathrm{s}$, test sonrası hiz $5 \mathrm{~mm} / \mathrm{s}$ olacak şekilde 5 kg'lık yük hücresi kullanılarak, 0.1 g'lık tetikleyici kuvvetle, prob ete değdikten sonra 4 s sıkıştırma yapılmıştır. Sıkıştırma işlemi örneklerin yüksekliklerinin yaklaşık \% 30'u olacak şekilde art arda 2 kez gerçekleştirilmiş ve sertlik-2, iç yapışkanlık, elastikiyet, sakızımsılık, dış yapışkanlık, çiğnenebilirlik ve esneklik değerleri elde edilmiştir (Bostan vd., 2001; Aylangan ve Vural, 2012).

\section{Duyusal Analizler}

Duyusal analizler depolama sirasinda belirlenen kontrol günlerinde 12 kişilik deneyimli panelist ekibi tarafindan yapılmıştır. Nugget örnekleri panelistlerce değerlendirilirken her grubun kendi içinde değerlendirilmesi gerektiği vurgulanmış ve örnekler ayrı ayrı sunulmuştur. Nuggetlar kızgın tavada iki yönü 2-3 dk 1sıtılarak tadımcilara sunulmuş ve analiz sırasında her bir örneğin tadımindan sonra panelistlere su ve tuzsuz galeta tüketmeleri tavsiye edilmiştir (Kolsarıc1 ve Candoğan, 1995). Duyusal değerlendirmede görünüş, renk, sululuk, koku, çiğnenebilirlik, lezzet ve genel beğeni özellikleri, 9'lu hedonik skala kullanılarak 1-9 arasında (9-Mükemmel, 8Çok iyi, 7-İyi, 6-Orta derecede iyi, 5-Orta, 4-Orta derecede kötü, 3-Kötü, 2-Çok kötü, 1-Aşırr kötü) puanlamaya tabi tutulmuştur.

\section{Mikrobiyolojik Analizler}

Toplam Mezofilik Aerobik Bakteri (TMAB), Toplam Psikrofilik Aerobik Bakteri (TPAB) ve Toplam Enterobacteriaceae sayımı için; nugget örneklerinden steril ortamda $10 \mathrm{~g}$ tartılmış aseptik koşullarda $90 \mathrm{~mL}$ Maximum Recovery Diluent (MRD) içine aktarılarak $2 \mathrm{dk}$ stomacher'da 
(MAYO homogenius HG400) homojenize edilmiştir. Daha sonra örneklerde gerekli seyreltmeler yapılarak TMAB ve TPAB sayımı için Plate Count Agar (PCA) besiyerine, Toplam Enterobacteriaceae sayımı için Violet Red Bile Dextrose (VRBD) Agar besiyerine dökme şeklinde ekim yapılmıştır. TMAB sayımı için $30^{\circ} \mathrm{C}$ 'de 24 saat inkübasyon, TPAB sayımı için ise $6.5^{\circ} \mathrm{C}$ 'de 10 gün inkübasyon sağlanmış ardından ilgili dilüsyonlardan sayım yapılmıstır. Toplam Enterobacteriaceae sayım için $37^{\circ} \mathrm{C}^{\prime} \mathrm{de} 24$ saat inkübasyon yapılmış ve VRBD Agar besiyerinde 0.5-2 mm çaplı koyu kırmızı renkli koloniler Enterobacteriaceae familyas1 üyeleri olarak sayılmıştır. Sonuçlar standart şekilde hesaplanarak $\mathrm{kob} / \mathrm{mL}$ olarak verilmiştir (Halkman, 2005).

Salmonella spp. analizi için $25 \mathrm{~g}$ örnek $225 \mathrm{~mL}$ tamponlanmıs peptonlu su içinde homojenize edilmiş ve ön zenginleştirme amacı ile $37^{\circ} \mathrm{C}^{\prime}$ de 18 saat inkübasyona bırakılmıştır. Selektif zenginleştirme amaciyla $10 \mathrm{~mL}$ Rappaport Vassiliadis Soy (RVS) Brotha ön zenginleştirme kültüründen $0.1 \mathrm{~mL}$ eklenmiş ve $41,5 \pm 1^{\circ} \mathrm{C}^{\prime} \mathrm{da} 24$ saat inkübasyona bırakılmıştır. Aynı amaçla $10 \mathrm{~mL}$ Muller-Kauffmann Tetrathionate/Novobiocin Brotha ön zenginleştirme kültüründen $1 \mathrm{~mL}$ eklenmiş ve $37^{\circ} \mathrm{C}$ de 24 saat inkübasyona bırakılmışır. İnkübasyondan sonra selektif zenginleştirme kültüründen Xylose Lysine Deoxycholate (XLD) Agar ve Brilliant Green Agar besiyerlerine öze ile ayr1 ayr1 sürme yapılmışır ve $37^{\circ} \mathrm{C}$ 'de 24 saat inkübasyona bırakılmışıtır. İnkübasyon sonunda oluşan tipik kolonilere ileri tanımlama testleri (Triple Sugar Iron (TSI) Agar'da gelişme, Üre Broth'da gelişme, Lisin Iron Agar'da gelişme) uygulanarak doğrulama yapılmıştır (ISO 6579:2002, 2012).

Listeria monocytogenes analiz için $25 \mathrm{~g}$ örnek $225 \mathrm{~mL}$ Fraser Broth (yarım konsantre) besiyerinde stomacher kullanilarak homojenize edilerek $30^{\circ} \mathrm{C}$ 'de 24 saat inkübe edilmiştir. $\mathrm{Bu}$ ön zenginleştirme kültüründen doğrudan ChromoCult Listeria Selective Agar (ALOA) ve/veya Palcam Agar selektif besiyerlerine sürme yapılmıştır. Ayrıca ön zenginleştirme kültüründen $10 \mathrm{~mL}$ Fraser Broth (tam konstare) besiyerine 0,1 $\mathrm{mL}$ aktarılarak $35-37^{\circ} \mathrm{C}$ de 48 saat inkübasyona bırakilmıştır. İnkübasyonun 24 ve 48. saatlerinde ALOA ve/veya Palcam Agar besiyerlerine sürme yapılarak $37^{\circ} \mathrm{C}$ 'de 24 saat inkübe edilmiştir. Listeria türleri öncelikle selektif katı besiyerlerinde oluşturdukları tipik koloniler ile tanımlanmıştır. Doğrulamanın ilk aşaması her Petriden Listeria şüpheli kolonilerin beşer tanesinin saflaştırma için Tryptic Soy Agar-Yeast Extract (TSYEA) besiyerinde kültüre alınarak, tipik Listeria kolonilerinin morfolojik olarak incelenmiş ardindan katalaz, hemoliz, karbonhidrat fermentasyon testleri yapılarak doğrulama yapilmıştır (ISO 11290, 1996).

\section{İstatistik Analiz}

İki tekerrürlü olarak yapılan çalışmada her bir tekerrürde analizler en az üç paralel olarak gerçekleştirilmiş ve her bir analiz için, SPSS 20.0 paket programı kullanilarak istatistik olarak değerlendirmeye tabi tutulmuştur. Varyans analizi tekniği (Anova) ile grup ortalamaları arasındaki fark belirlenmiş, bu farklıllğın önem derecesi ise Tukey çoklu karşllaştırma testi yapılarak incelenmiştir.

\section{BULGULAR VE TARTIŞMA \\ Örneklerin kimyasal bileşimi}

Bıldırcın karışımlı nugget (BN) ile piliç nugget (PN) örneklerinin su, yağ, ham protein, kül analizi sonuçları ve yağ asitleri bileşimi Çizelge 1'de verilmiştir. Buna göre $\mathrm{BN}$ örneklerinin daha yüksek su, protein ve daha düşük yağ ve kül içeriğine sahip olduğu tespit edilmiştir. BN örneklerinin protein oranının yüksek, yağ oranının düşük olmasının tüketiciler için tercih sebebi olacağ1 düşünülmektedir. Ticari nugget örneklerinin kimyasal kompozisyonun araştırıldığ1 bir çalışmada örneklerin su, protein, yağ ve kül değerleri çalışmamızla uyumlu olarak sirasıyla $\% 34.71-56.51, \quad \% 12.52-16.62, \quad \% 18.14-25.00$, \%1.20-1.58 olarak belirlenmiştir (Lukman vd. 2009). Yağ asitleri bileşimi analizinde BN ile PN örneklerinin sonuçları arasında farklılıkların olduğu, BN örneklerinde linolenik, stearik ve palmitik asitlerin PN'ye oranla daha yüksek olduğu tespit edilmiştir. 


\section{Çizelge 1. Örneklerin kimyasal bileşimi}

Table 1. Chemical composition of samples

\begin{tabular}{lcc}
\hline & $\mathrm{BN}(\%)$ & PN (\%) \\
\hline Su İçeriği (water content) & $55.97 \pm 0.88$ & $54.87 \pm 0.35$ \\
Yağ İçriği (lipid content) & $8.84 \pm 0.37$ & $9.61 \pm 0.17$ \\
Ham Protein İçeriği (raw protein content) & $16.17 \pm 0.73$ & $13.10 \pm 0.33$ \\
Kül İçriği (ash content) & $2.08 \pm 0.51$ & $2.18 \pm 0.06$ \\
\hline Yağ Asitleri (fatty acids) & $\mathrm{BN}(\%)$ & $\mathrm{PN}(\%)$ \\
\hline Behenik asit (Behenic acid) (C22:0) & 0.58 & 0.20 \\
Oleik asit (Oleic acid) (C18:1) & 10.38 & 32.15 \\
Dokosadienoik asit metil ester (Docosadienoik acid methyl ester) (C22:2) & - & 0.09 \\
Heneikosanoik asit metil ester (Heneicosanoic acid methyl ester) (C21:0) & - & 0.05 \\
Linoelaidik asit (Linoelaidic acid) (C18:2 Trans) & 11.08 & 0.06 \\
Linoleik asit (Linoleic acid) (C18:2 Cis) & 21.55 & 46.54 \\
Linolenik asit (Linolenic acid) (C18:3 Cis) & 21.78 & 1.30 \\
Miristik asit (Myristic acid) (C14:0) & 0.21 & 0.23 \\
Palmitik asit (Palmitic acid) (C16:0) & 19.18 & 13.13 \\
Palmitoleik asit (Palmitoleic acid) (C16:1) & 1.52 & 1.56 \\
Stearik asit (Stearic acid) (C18:0) & 13.72 & 4.68 \\
\hline
\end{tabular}

\section{Kimyasal Analiz Bulguları pH Değeri}

Depolama süresince $\mathrm{BN}$ ve $\mathrm{PN}$ örneklerine ait $\mathrm{pH}$ değerleri Çizelge 2'de verilmiştir. Soğuk depolamada BN örneklerindeki en yüksek $\mathrm{pH}$ değeri 6.45 olarak 20. günde, donmuş depolamada ise 6.44 olarak 60. günde gözlenmiştir. BN için her iki depolama sicaklığında da depolamanın sonunda, başlangıç $\mathrm{pH}$ değerine göre bir artışın meydana geldiği, PN için ise başlangıç $\mathrm{pH}$ değerine göre bir azalmanın meydana geldiği tespit edilmiştir. BN'lerin soğuk depolanması boyunca PN'lerin ise soğuk ve donmuş depolanması boyunca başlangıç ve bitiş değerleri arasındaki farklılık istatistik açıdan önemli bulunmuştur $(P \quad$ <0.05). Benzer şekilde Choudhary vd. (2019) bildırcin nugget örneklerini $4{ }^{\circ} \mathrm{C}$ 'de 20 gün boyunca depoladıkları çalışmalarında depolama sonunda $\mathrm{pH}$ değerinde önemli düzeyde bir artı̧s olduğunu tespit etmişlerdir. BN ile PN'nin depolama süresince $\mathrm{pH}$ değerleri arasındaki farklılık karşılaştırıldığında sadece donmuş depolamanın 60 ve 90 . günlerdeki değişimlerin istatistik açıdan önemli olduğu tespit edilmiştir $(P \quad<0.05)$. Depolamanın farklı günlerinde görülen bu $\mathrm{pH}$ değişikliklerinin, gerçekleşen enzimatik reaksiyonlar ve mikroorganizma faaliyeti yanında üretimde kullanılan çeşitli katk1 maddelerinden kaynaklandığı düşünülmektedir.

\section{Serbest Yağ Asitliği Değeri}

Depolama süresince $\mathrm{BN}$ ve $\mathrm{PN}$ örneklerine ait SYA değerleri Çizelge 3'te verilmiştir. Depolama süresi boyunca $\mathrm{BN}$ örneklerinin SYA değerindeki değişim istatistik açıdan önemli bulunmamıştır $(P$ $>0.05)$. Soğuk depolamada en yüksek SYA değeri, BN örneklerinde $2.95 \%$ oleik asit olarak 20. günde; PN örneklerinde $3.15 \%$ oleik asit olarak 15. günde tespit edilmiştir. Depolamanın 90. ve 120. günlerde BN örneklerinin SYA değerlerinin, PN örneklerinin SYA değerlerinden istatistik açıdan önemli düzeyde yüksek olduğu tespit edilmiştir $(P<0.05)$. Kolsarıc1 (2004) et ve et ürünlerinde SYA'nın, depolama boyunca hidrolize uğrayarak peroksitlere ve diğer ürünlere parçalanmaktayken bir kısmının da üründe birikerek miktarının arttı̆̆ını, depolama sıcaklığının da SYA değerine etki etmekte olup sıcaklığın azalması ile SYA değerinin düştüğünü belirtmiştir. Bayrak (2011) da yapmış olduğu çalışmada, et ürünlerinde SYA değerinin depolama ile arttığını belirtmiştir.

\section{Peroksit ve Tiyobarbitürik Asit Değerleri}

Et ve et ürünlerinde lipit oksidasyonu sonucunda birincil ve ikincil reaksiyon ürünleri oluşur ve oluşan bu bileşenler de etin renk, aroma, lezzet, yap1 ve aynı zamanda esansiyel yağ asitleri ve yağda eriyen vitaminlerinde kayba sebep olur. Sonuçta da raf ömründe azalma ve ileri düzeyde oksidasyon oluşumunda da toksik bileşikler 
oluşur. Birincil oksidasyon düzeyinin tespit edilmesi için peroksit değerinin, ikincil oksidasyon düzeyinin tespit edilmesi için ise TBA değerinin belirlenmesi en yaygin olarak kullanılan yöntemlerdir (Demirkaya, 2013).

Çizelge 2. Örneklerin depolama boyunca $\mathrm{pH}$ değerleri

Table 2. pH values of samples during storage

\begin{tabular}{|c|c|c|c|c|}
\hline $\begin{array}{l}\text { Depolama sicaklığ } 1 \\
\text { Storage temperature }\end{array}$ & $\begin{array}{l}\text { Depolama süresi (gün) } \\
\text { Storage time (days) }\end{array}$ & $\mathrm{BN}$ & $\mathrm{PN}$ & $\mathrm{P}$ \\
\hline \multirow{6}{*}{$\begin{array}{l}\cup \\
0 \\
+\end{array}$} & 0 & $6.33 \mathrm{bc} \pm 0.05$ & $6.54 \mathrm{a} \pm 0.01$ & 0.219 \\
\hline & 5 & $6.29 \mathrm{c} \pm 0.01$ & $6.38^{\mathrm{b}} \pm 0.03$ & 0.145 \\
\hline & 10 & $6.37 \mathrm{abc} \pm 0.01$ & $6.52 \mathrm{a} \pm 0.01$ & 0.609 \\
\hline & 15 & $6.43 \mathrm{ab} \pm 0.01$ & $6.46^{\mathrm{ab}} \pm 0.02$ & 0.089 \\
\hline & 20 & $6.45^{a} \pm 0.03$ & $5.96 \mathrm{c} \pm 0.08$ & 0.172 \\
\hline & $\mathrm{P}$ & 0.014 & 0.00 & \\
\hline \multirow{5}{*}{$\begin{array}{l}\text { U } \\
\infty \\
\rightarrow \\
\rightarrow\end{array}$} & 30 & $6.36^{\mathrm{bc}} \pm 0.01$ & $6.60^{\mathrm{b}} \pm 0.05$ & 0.100 \\
\hline & 60 & $6.44^{\mathrm{Aa}} \pm 0.00$ & $6.70^{\mathrm{Ba}} \pm 0.03$ & 0.026 \\
\hline & 90 & $6.32 \mathrm{Ac} \pm 0.01$ & $6.59 \mathrm{Bb} \pm 0.03$ & 0.043 \\
\hline & 120 & $6.39 \mathrm{ab} \pm 0.03$ & $6.47 \mathrm{c} \pm 0.01$ & 1.000 \\
\hline & $\mathrm{P}$ & 0.008 & 0.000 & \\
\hline
\end{tabular}

a, b. c: Aynı sütunda farklı harflerle gösterilen ortalamalar istatistik açıdan birbirinden farklıdır $(P<0.05)$.

A, B: Aynı satırda farklı harflerle gösterilen ortalamalar istatistik açıdan birbirinden farklıdır $(P<0.05)$.

a, b. c: The averages of different letters in the same column are statistically different $(P<0.05)$.

$A, B$ : The averages shown in different letters on the same line are statistically different $(P<0.05)$.

Çizelge 3. Örneklerin depolama boyunca SYA değerleri

Table 3. FFA values of samples during storage

\begin{tabular}{|c|c|c|c|c|}
\hline Depolama sicakliğ1 & Depolama süresi (gün) & $\mathrm{BN}$ & PN & $\mathrm{P}$ \\
\hline \multirow{6}{*}{$\begin{array}{l}\cup \\
\text { O }\end{array}$} & 0 & $2.35 \pm 0.33$ & $2.27 \mathrm{~b} \pm 0.09$ & 0.334 \\
\hline & 5 & $2.29 \pm 0.18$ & $2.16^{\mathrm{b}} \pm 0.02$ & 0.096 \\
\hline & 10 & $2.27 \pm 0.16$ & $2.30^{\mathrm{b}} \pm 0.29$ & 0.101 \\
\hline & 15 & $2.51 \pm 0.26$ & $3.15^{\mathrm{a}} \pm 0.22$ & 0.704 \\
\hline & 20 & $2.95 \pm 0.43$ & $2.89 \mathrm{a} \pm 0.29$ & 0.911 \\
\hline & $\mathrm{P}$ & 0.249 & 0.00 & \\
\hline \multirow{5}{*}{$\begin{array}{l}\cup \\
\circ \\
\stackrel{\infty}{\rightarrow}\end{array}$} & 30 & $3.01 \pm 0.36$ & $2.32^{\mathrm{a}} \pm 0.24$ & 0.943 \\
\hline & 60 & $2.44 \pm 0.39$ & $2.18^{a b} \pm 0.03$ & 0.155 \\
\hline & 90 & $2.96^{\mathrm{A}} \pm 0.03$ & $1.75^{\mathrm{Bb}} \pm 0.24$ & 0.038 \\
\hline & 120 & $3.09^{\mathrm{A}} \pm 0.10$ & $2.37 \mathrm{Ba} \pm 0.26$ & 0.027 \\
\hline & $\mathrm{P}$ & 0.211 & 0.029 & \\
\hline
\end{tabular}

a, b. c: Aynı sütunda farklı harflerle gösterilen ortalamalar istatistik açıdan birbirinden farklıdır $(P<0.05)$.

A, B: Aynı satırda farklı harflerle gösterilen ortalamalar istatistik açıdan birbirinden farklıdır $(P<0.05)$.

a, b. c: The averages of different letters in the same column are statistically different $(P<0.05)$.

$A, B:$ The averages shown in different letters on the same line are statistically different $(P<0.05)$.

Depolama süresince $\mathrm{BN}$ ve $\mathrm{PN}$ örneklerine ait TBA değerleri Çizelge 4'te verilmiştir. Depolama süreci boyunca $\mathrm{BN}$ örneklerinde, TBA değerindeki değişim istatistik açıdan önemli bulunmamıştır ( $P$ >0.05). Diğer taraftan Choudhary vd. (2019), bildırcin nugget örneklerinin $4^{\circ}$ C'de 20 günlük depolama sonucundan TBA değerinde önemli bir atış olduğunu belirlemişler ve bu artışın sebebinin ambalaj materyalinin oksijen geçirgenliği ile ilgili olabileceğini ifade etmişlerdir. Çizelge 4'te TBA değerlerinde bazı artış ve azalışların olduğu 
görülmektedir. TBA değerinde ki mevcut artış ve azalısslarin sebebinin ise oksidasyon ara ürünlerinin farklılaşmasından kaynaklandığ1 düşünülmektedir. Rinaldi vd. (2014), TBA değerinde artış ve azalışlanın olmasını oksidasyon bileşenlerinin yüksek derecede reaktif olması sonucu etteki protein ve aminoasit gibi bileşenlerle reaksiyona girerek miktarlarının değişmesinden kaynaklandığını bildirmiştir. Demirkaya (2014), TBA değerinde görülen artış ve azalışların hidrojen peroksitlerin yapısında bulunan malonaldehitin stabil olmayan yapisindan kaynaklandığını belirtmiş, yine hammadde ve/veya üretim tekniklerindeki farklllıklardan ve depolama şartlarından kaynaklı bazı farklılıklar olabileceğini de bildirmiştir. $\mathrm{BN}$ ile PN örneklerinin TBA değerindeki değişimlerin karşılaştırılmasında, yalnızca 15. günde PN'lerin önemli düzeyde yüksek TBA değerine sahip olduğu gözlemlenmiştir $(P<0.05)$.

Çizelge 4. Örneklerin depolama boyunca TBA değerleri (mg malonaldehit / kg örnek)

Table 4. TBA values of samples during storage ( $\mathrm{mg}$ malonaldehyde / $\mathrm{kg}$ sample)

\begin{tabular}{|c|c|c|c|c|}
\hline $\begin{array}{l}\text { Depolama sicaklığ1 } \\
\text { Storage temperature }\end{array}$ & $\begin{array}{c}\text { Depolama süresi (gün) } \\
\text { Storage time (davs) }\end{array}$ & $\mathrm{BN}$ & $\mathrm{PN}$ & $\mathrm{P}$ \\
\hline \multirow{6}{*}{$\begin{array}{l}\cup \\
\dot{\sigma} \\
+\end{array}$} & 0 & $1.37 \pm 0.14$ & $2.05^{b} \pm 0.39$ & 0.088 \\
\hline & 5 & $1.62 \pm 0.45$ & $1.22 \mathrm{c} \pm 0.03$ & 0.147 \\
\hline & 10 & $1.30 \pm 0.07$ & $2.16^{\mathrm{b}} \pm 0.15$ & 0.103 \\
\hline & 15 & $1.48^{\mathrm{A}} \pm 0.01$ & $2.53^{\mathrm{Bab}} \pm 0.13$ & 0.021 \\
\hline & 20 & $1.59 \pm 0.06$ & $2.74^{a} \pm 0.09$ & 0.343 \\
\hline & $\mathrm{P}$ & 0.564 & 0.00 & \\
\hline \multirow{5}{*}{$\begin{array}{l}\cup \\
0 \\
\infty \\
+1\end{array}$} & 30 & $1.64 \pm 0.22$ & $1.25^{\mathrm{a}} \pm 0.06$ & 0.353 \\
\hline & 60 & $1.38 \pm 0.09$ & $1.12^{\mathrm{b}} \pm 0.03$ & 0.298 \\
\hline & 90 & $1.55 \pm 0.08$ & $1.04 \mathrm{~b} \pm 0.04$ & 0.709 \\
\hline & 120 & $1.65 \pm 0.15$ & $0.90^{c} \pm 0.06$ & 0.996 \\
\hline & $\mathrm{P}$ & 0.302 & 0.000 & \\
\hline
\end{tabular}

a, b. c: Aynı sütunda farklı harflerle gösterilen ortalamalar istatistik açıdan birbirinden farklıdır $(P<0.05)$.

A, B: Aynı satırda farklı harflerle gösterilen ortalamalar istatistik açıdan birbirinden farklıdır $(P<0.05)$.

a, b. c: The averages of different letters in the same column are statistically different $(P<0.05)$.

$A, B$ : The averages shown in different letters on the same line are statistically different $(P<0.05)$.

Depolama süresince $\mathrm{BN}$ ve $\mathrm{PN}$ örneklerine ait peroksit değerleri Çizelge 5’te verilmiştir. Her iki depolama boyunca örneklerin başlangıç ve bitiş peroksit değerindeki değişim istatistik açıdan önemli bulunmuştur $(P<0.05)$. Buna ilave olarak her iki nugget örneğinin peroksit değerinin soğuk depolamada arttığı, donmuş depolamada ise azaldığ1 tespit edilmiştir. Depolama süresi boyunca $\mathrm{BN}$ ve PN örneklerinin peroksit değerindeki değişimler kıyaslandığında sadece 5 . günde PN'deki yüksek peroksit değerinin istatistik açıdan önemli olduğu görülmüştür $(P<0.05)$. Kolsarıc1 (2004) et ve et ürünlerinde lipit oksidasyonunun primer ürünlerinden hidroperoksitlerin oksidasyonunun göstergesi olduğunu ve bu değerlerin de depolama sıcaklığına bağlı olarak değişebileceğini belirtmiştir.

\section{Su Aktivitesi Değeri}

Depolama süresince $\mathrm{BN}$ ve $\mathrm{PN}$ örneklerine ait $\mathrm{a}_{\mathrm{w}}$ değerleri Çizelge 6'da verilmiştir. Et ve et ürünlerinde mikroorganizmaların yașama ve çoğalması $a_{w}$ değeri ile yakından ilişkilidir. Depolama ile $\mathrm{a}_{\mathrm{w}}$ değerinde düşüşlerin meydana geldiği gözlemlenmiştir. $\mathrm{BN}$ ve $\mathrm{PN}$ örnekleri arasındaki farklılığa bakıldığında $\mathrm{a}_{\mathrm{w}}$ değerlerinin soğuk depolama ve donmuş depolama boyunca istatistik açıdan önemli bir değişim göstermediği tespit edilmiştir $(P>0.05)$. Donmuş depolamadaki BN örneklerinin başlangıç ve bitiş $a_{w}$ değerindeki değişim istatistik açıdan önemli bulunmuştur ( $P$ <0.05). Ancak donmuş depolamadaki PN örneklerindeki değişim istatistik açıdan önemli bulunmamıştır $(P>0.05)$. 
Çizelge 5. Örneklerin depolama boyunca peroksit değerleri (meq $\mathrm{O}_{2} / \mathrm{kg}$ yağ) Table 5. Peroxide values of samples during storage (meq $\mathrm{O}_{2} / \mathrm{kg}$ lipid)

\begin{tabular}{ccccc}
\hline $\begin{array}{c}\text { Depolama sicaklığ } 1 \\
\text { Storage temperature }\end{array}$ & $\begin{array}{c}\text { Depolama Süresi (gün) } \\
\text { Storage time (days) }\end{array}$ & $\mathrm{BN}$ & $\mathrm{PN}$ & $\mathrm{P}$ \\
\hline & 0 & $0.00^{\mathrm{b}} \pm 0.00$ & $0.00^{\mathrm{d} \pm 0.00}$ & - \\
$\mathbf{5}$ & 5 & $0.00^{\mathrm{Ab}} \pm 0.00$ & $7.33^{\mathrm{Bc}} \pm 0.11$ & 0.016 \\
+ & 10 & $15.83^{\mathrm{a}} \pm 4.56$ & $24.71^{\mathrm{b}} \pm 0.32$ & 0.151 \\
& 15 & $21.95^{\mathrm{a}} \pm 0.22$ & $27.10^{\mathrm{a}} \pm 1.15$ & 0.068 \\
& 20 & $22.56^{\mathrm{a}} \pm 1.42$ & $23.75^{\mathrm{b}} \pm 0.59$ & 0.564 \\
\hline & 0.000 & 0.000 & \\
\hline & 30 & $22.59^{\mathrm{a}} \pm 3.79$ & $18.93^{\mathrm{a}} \pm 1.46$ & 0.502 \\
$\infty$ & 60 & $16.90^{\mathrm{a}} \pm 0.11$ & $14.10^{\mathrm{b}} \pm 0.19$ & 0.118 \\
$\infty$ & 90 & $11.61^{\mathrm{b}} \pm 1.31$ & $14.33^{\mathrm{b}} \pm 0.65$ & 0.742 \\
& 120 & $9.21^{\mathrm{b}} \pm 1.80$ & $14.70^{\mathrm{b}} \pm 1.81$ & 0.384 \\
\hline & $\mathrm{P}$ & 0.013 & 0.004 & \\
\hline
\end{tabular}

a, b. c: Aynı sütunda farklı harflerle gösterilen ortalamalar istatistik açıdan birbirinden farklıdır $(P<0.05)$.

A, B: Aynı satırda farklı harflerle gösterilen ortalamalar istatistik açıdan birbirinden farklıdır $(P<0.05)$.

a, b. c: The averages of different letters in the same column are statistically different $(P<0.05)$.

$A, B$ : The averages shown in different letters on the same line are statistically different $(P<0.05)$.

Çizelge 6. Örneklerin depolama boyunca su aktivitesi değerleri

Table 6. $a_{w}$ values of samples during storage

\begin{tabular}{ccccc}
\hline $\begin{array}{l}\text { Depolama sicaklığ1 } \\
\text { Storage temperature }\end{array}$ & $\begin{array}{c}\text { Depolama Süresi (gün) } \\
\text { Storage time (days) }\end{array}$ & $\mathrm{BN}$ & $\mathrm{PN}$ & $\mathrm{P}$ \\
\hline & 0 & $0.95 \pm 0.00$ & $0.96 \pm 0.01$ & 0.561 \\
$\mathrm{O}$ & 5 & $0.95 \pm 0.00$ & $0.95 \pm 0.01$ & 0.116 \\
+ & 10 & $0.95 \pm 0.00$ & $0.94 \pm 0.01$ & 0.561 \\
& 15 & $0.96 \pm 0.01$ & $0.95 \pm 0.01$ & 0.184 \\
20 & $0.95 \pm 0.00$ & $0.95 \pm 0.02$ & 0.184 \\
$\mathrm{P}$ & 0.360 & 0.264 & \\
\hline & 30 & $0.95 \mathrm{a} \pm 0.01$ & $0.95 \pm 0.01$ & 0.184 \\
0 & 60 & $0.93 \mathrm{ab} \pm 0.00$ & $0.94 \pm 0.00$ & 0.116 \\
$\infty$ & 90 & $0.94 \mathrm{ab} \pm 0.00$ & $0.95 \pm 0.01$ & 0.561 \\
$\rightarrow$ & 120 & $0.93 \mathrm{~b} \pm 0.01$ & $0.94 \pm 0.01$ & 0.116 \\
& $\mathrm{P}$ & 0.049 & 0.363 & \\
\hline
\end{tabular}

a, b. c: Aynı sütunda farklı harflerle gösterilen ortalamalar istatistik açıdan birbirinden farklıdır $(P<0.05)$.

A, B: Aynı satırda farklı harflerle gösterilen ortalamalar istatistik açıdan birbirinden farklıdır $(P<0.05)$.

a, b. c: The averages of different letters in the same column are statistically different $(P<0.05)$.

$A, B$ : The averages shown in different letters on the same line are statistically different $(P<0.05)$.

\section{Tekstür Analizi}

Etin tekstürü müşteriler tarafindan etin kabul edilebilirliğinde etkili bir parametre olmas1 nedeniyle et ürünlerinde oldukça önem arz etmektedir (Ertaş ve Doğruer, 2010). Her iki depolama süresi boyunca $\mathrm{BN}$ ve $\mathrm{PN}$ örneklerine ait TPA ve kesme analizi değerleri Çizelge 7'de verilmiştir. BN örneklerinin soğuk depolamada sertlik-2, sakızımsılık, çiğnenebilirlik ve sıkılık değerlerindeki değişikliklerin istatistik açıdan önemli olduğu $(P<0.05)$; donmuş depolanan örneklerde ise sertlik-1, sertlik-2, elastikiyet, sakızımsılık, çiğnenebilirlik, sıkılık ve esneklik değerleri arasında önemli farkllikllar olduğu belirlenmiştir $(P<0.05)$. PN örneklerinde ise soğuk depolamada sertlik-1 ve sıkılık değerleri dışında TPA değerindeki değişimler istatistik açıdan önemli bulunmamıştır $(P>0.05)$; donmuş depolamada ise sertlik-1, sertlik-2, dış yapışkanlık, sakızımsılık, çiğnenebilirlik, sık1lık ve esneklik değerlerindeki değişimlerin istatistik açıdan önemli olduğu belirlenmiștir $(P<0.05)$. 
Çizelge 7. Örneklerin depolama boyunca tekstür analiz sonuçları Table 7. Texture analysis results of samples during storage

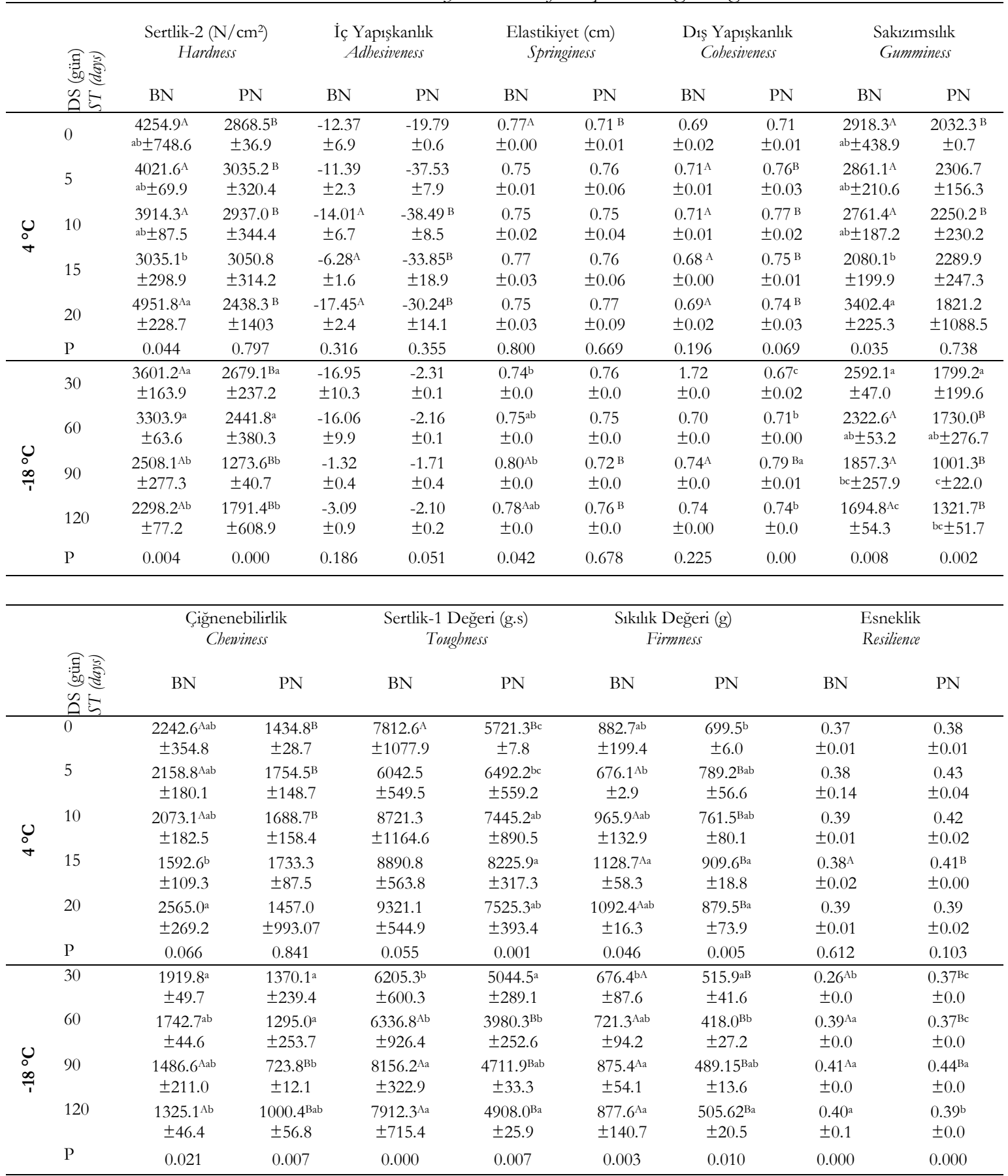

DS: Depolama süresi (gün); a, b. c: Aynı sütunda farklı harflerle gösterilen ortalamalar istatistik açıdan birbirinden farklidır $(P<0.05)$.

A, B: Aynı satırda farklı harflerle gösterilen ortalamalar istatistik açıdan birbirinden farklıdır $(P<0.05)$.

ST: Storage time (days); $a, b$. c: The averages of different letters in the same column are statistically different $(P<0.05)$.

$A, B$ : The averages shown in different letters on the same line are statistically different $(P<0.05)$. 


\section{Renk Analiz Bulguları}

İleri işlenmiş ürünlerde istenen renk; hammadde, kullanılan kaplama materyali, pişirme yöntemi, üretimde kullanılan katkı maddeleri, kızartma yağının sıcaklığı, çeşidi, kullanım süresi ya da s1kllğ1 gibi etkilere bağlıdır (Gökçe vd., 2016). Depolama süresince $\mathrm{BN}$ ve $\mathrm{PN}$ örneklerine ait renk $\left(L^{*}, a^{*}\right.$ ve $\left.b^{*}\right)$ değerleri Çizelge 8 'de verilmiştir. $\mathrm{BN}$ örneklerinin soğuk depolama ve donmuş depolama boyunca $L^{*}$, $a^{*}$ ve $b^{*}$ değerlerindeki farkların istatistik açıdan önemli olmadığ1 görülmüştür $(P>0.05)$. Bu farklilığın üretimde kullanılan et türünün farklı olmasıly ilişkili olduğu düşünülmektedir. $\mathrm{BN}$ ve $\mathrm{PN}$ örneklerinin $L^{*}, \quad a^{*}$ ve $b^{*}$ değerleri karşılaştırıldığında $L^{*}$ değerinin soğuk depolamanın 5. gününde, $a^{*}$ değerinin soğuk depolamanın 0 . ve 15 . gününde, $b^{*}$ değerinin soğuk depolamanın 0 , 5 . ve 20 . gününde gösterdiği farklılıkların istatistik açıdan önemli olduğu tespit edilmiştir $(P<0.05)$. Hem pigmenti, myoglobin, demir ve $a^{*}$ değeri arasında pozitif bir korelasyon bulunmaktayken hem pigmenti, myoglobin, demir ve $L^{*}$ değeri arasında negatif bir korelasyon bulunmaktadır (Boulianne ve King, 1995). Çeşitli kaynaklarda bıldırcın etinde bulunan demir miktarının piliç etine oranla daha fazla olduğu belirtilmektedir. Buna göre çalışma ile paralel bir şekilde BN'lerde $L^{*}$ değerinin daha düşük; $a^{*}$ değerinin ise PN'ye göre daha yüksek rakamlarda olduğu görülmektedir. Bayrak (2011) lipit oksidasyonunun ilerlemesine bağlı olarak pigment oksidasyonunun arttığını böylece de $b^{*}$ değerlerinin azaldığını belirtmektedir. Lukman vd. (2009) ticari nugget örneklerinin fizikokimyasal özelliklerini araştırdığı çalışmasında farklı markalara ait nugget örneklerinin $L^{*}, a^{*}$ ve $b^{*}$ değerlerini sirasiyla 64.38-68.41, 0.51-3.51 ve 16.46-19.35 olarak belirlemiştir. Çalışmamızda BN'ye ait a değerlerinin Lukman vd. (2009)'da verilen değerlerin üzerinde, $b$ değerinin ise aynı çalışmadaki değerlerin altında kaldığ görülmektedir.

Çizelge 8. Örneklerin depolama boyunca $\mathrm{L}^{*}, \mathrm{a}^{*}, \mathrm{~b}^{*}$ değerleri Table 8. $L^{*}, a^{*}, b^{*}$ values of samples during storage

\begin{tabular}{|c|c|c|c|c|c|c|c|}
\hline & \multirow{3}{*}{$\begin{array}{l}\text { DS (gün) } \\
S T \text { (days) }\end{array}$} & \multicolumn{6}{|c|}{$\begin{array}{l}\text { Renk değerleri } \\
\text { Color value }\end{array}$} \\
\hline & & \multicolumn{2}{|c|}{$L^{*}$} & \multicolumn{2}{|c|}{$a^{*}$} & \multicolumn{2}{|c|}{$b^{*}$} \\
\hline & & $\mathrm{BN}$ & PN & BN & PN & $\mathrm{BN}$ & PN \\
\hline \multirow{6}{*}{$\begin{array}{l}0 \\
0 \\
+\end{array}$} & 0 & $64.74 \pm 0.68$ & $75.24 \pm 1.22$ & $5.25^{\mathrm{A}} \pm 0.08$ & $1.17^{\mathrm{Bb}} \pm 0.84$ & $15.49^{\mathrm{A}} \pm 0.11$ & $15.09^{\mathrm{B}} \pm 1.50$ \\
\hline & 5 & $62.82^{\mathrm{A}} \pm 0.32$ & $76.96^{\mathrm{B}} \pm 2.19$ & $5.45 \pm 0.30$ & $2.14 \mathrm{ab} \pm 0.15$ & $15.72^{\mathrm{A}} \pm 0.40$ & $16.03^{\mathrm{B}} \pm 1.07$ \\
\hline & 10 & $64.64 \pm 0.31$ & $75.42 \pm 0.54$ & $5.57 \pm 0.16$ & $2.37^{\mathrm{a}} \pm 0.08$ & $15.95 \pm 0.54$ & $16.67 \pm 0.45$ \\
\hline & 15 & $63.27 \pm 1.79$ & $74.04 \pm 1.62$ & $5.42^{\mathrm{A}} \pm 0.10$ & $1.97^{\mathrm{Bab}} \pm 0.35$ & $14.83 \pm 0.46$ & $15.82 \pm 0.21$ \\
\hline & 20 & $64.49 \pm 0.05$ & $75.84 \pm 0.32$ & $5.74 \pm 0.00$ & $2.55^{\mathrm{a}} \pm 0.15$ & $15.22^{\mathrm{A}} \pm 0.23$ & $15.00^{\mathrm{B}} \pm 0.77$ \\
\hline & $\mathrm{P}$ & 0.228 & 0.207 & 0.154 & 0.020 & 0.156 & 0.225 \\
\hline \multirow{5}{*}{ 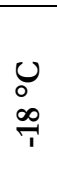 } & 30 & $64.45 \pm 2.47$ & $76.84^{b} \pm 0.85$ & $4.97 \pm 0.06$ & $1.08^{\mathrm{b}} \pm 0.05$ & $15.30 \pm 0.28$ & $16.19^{\mathrm{b}} \pm 0.14$ \\
\hline & 60 & $64.90 \pm 0.42$ & $76.69^{b} \pm 0.63$ & $5.07 \pm 0.37$ & $1.03^{\mathrm{b}} \pm 0.24$ & $15.90 \pm 0.42$ & $16.05^{\mathrm{b}} \pm 0.06$ \\
\hline & 90 & $65.80 \pm 0.28$ & $77.23^{\mathrm{ab}} \pm 0.13$ & $4.93 \pm 0.18$ & $1.46^{a} \pm 0.10$ & $15.75 \pm 0.21$ & $16.29^{b} \pm 0.31$ \\
\hline & 120 & $65.70 \pm 0.28$ & $78.31^{\mathrm{a} \pm 0.27}$ & $5.06 \pm 0.34$ & $0.78^{\mathrm{b}} \pm 0.04$ & $15.85 \pm 0.63$ & $17.12^{\mathrm{a}} \pm 0.16$ \\
\hline & $\mathrm{P}$ & 0.691 & 0.026 & 0.929 & 0.002 & 0.537 & 0.000 \\
\hline
\end{tabular}

DS: Depolama süresi (gün); a, b. c: Aynı sütunda farklı harflerle gösterilen ortalamalar istatistik açıdan birbirinden farklidir $(P<0.05)$.

A, B: Aynı satırda farklı harflerle gösterilen ortalamalar istatistik açıdan birbirinden farklıdır $(P<0.05)$.

ST: Storage time (days); a, b. c: The averages of different letters in the same column are statistically different $(P<0.05)$.

$A, B$ : The averages shown in different letters on the same line are statistically different $(P<0.05)$.

\section{Duyusal Analiz Bulguları}

Depolama süresince $\mathrm{BN}$ ve $\mathrm{PN}$ örneklerine ait duyusal analiz değerleri Çizelge 9'da verilmiştir. $\mathrm{BN}$ örneklerinde soğuk depolama süresince yapılan duyusal analizlerde dış renk ve koku puanlarındaki değişimin istatistik açıdan önemli olduğu $(P<0.05)$ ancak görünüş, iç renk, sululuk, çiğnenebilirlik, lezzet ve genel beğeni puanlarındaki değişimlerin istatistik açıdan önemli olmadığı belirlenmiştir $(P>0.05)$. Choudhary vd. 
(2019) ise çalışmalarında $4^{\circ} \mathrm{C}$ 'de 20 gün boyunca depolanan bildırcin nugget örneklerinin genel beğeni puanının $7.28 \pm 0.03$ 'ten $5.62 \pm 0.05$ 'e düştüğü ve önemli düzeyde bir azalış gösterdiğini bildirmiştir $(P<0.05)$ Donmuş depolamada ise duyusal analiz parametrelerindeki değişimlerin istatistik açıdan önemli olmadığ görülmüştür $(P$ $>0.05)$. BN ve $P N$ örnekleri karşılaştırıldığında ise bazı farklılıklar tespit edilmiştir. $\mathrm{BN}$ ve $\mathrm{PN}$ örneklerinin görünüş puanı karşılaştırıldığında; soğuk depolamanın 10. günü ile donmuş depolamanın 120. gününde, koku puan1 karşılaştırıldığında soğuk depolamanın 10 ve 20 . gününde, lezzet puanı karşılaştırıldığında soğuk depolamanın 5,10 ve 20 . gününde, genel beğeni puanı karşılaştıılldığında ise soğuk depolamanın 0 , 5, 10 ve 20. günlerdeki farkll1kklarin istatistik açıdan önemli olduğu tespit edilmiştir $(P>0.05)$. Soğuk depolamada BN örneklerinin başlangiç diş renk puanının 5. günde önemli oranda düştüğü $(P$ $<0.05)$ ardından 10. günde önemli oranda arttığ1 $(P<0.05)$ ve sonrasındaki değişimin istatistik açıdan önemli olmadığı tespit edilmiştir $(P>0.05)$. Soğuk depolamada BN örneklerinin koku puanlarında başlangıca göre 10. gündeki artış istatistik açıdan önem taşırken sonrasında soğuk depolamanın son gününe kadarki değişimlerin istatistik açıdan önemli olmadığı görülmüştür $(P$ $>0.05$ ).

Çizelge 9. Örneklerin depolama boyunca duyusal analiz sonuçları

Table 9. Sensory analysis values of samples during storage

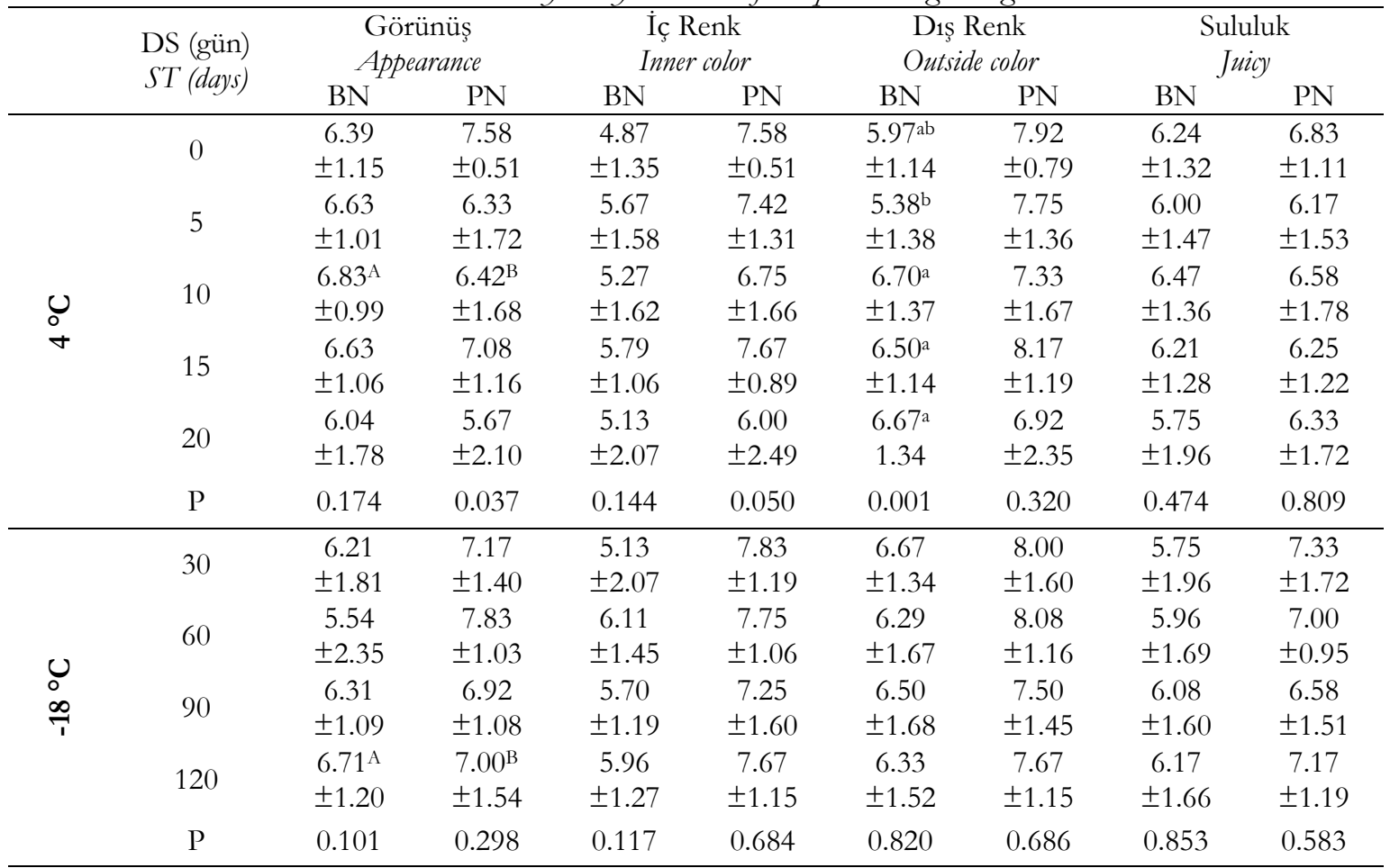

DS: Depolama süresi (gün); a, b. c: Aynı sütunda farklı harflerle gösterilen ortalamalar istatistik açıdan birbirinden farklidir $(P<0.05)$.

A, B: Aynı satırda farklı harflerle gösterilen ortalamalar istatistik açıdan birbirinden farklıdır $(P<0.05)$.

ST: Storage time (days); $a, b$. c: The averages of different letters in the same column are statistically different $(P<0.05)$.

$A, B:$ The averages shown in different letters on the same line are statistically different $(P<0.05)$. 
Çizelge 9. Örneklerin depolama boyunca duyusal analiz sonuçları (devam) Table 9. Sensory analysis values of samples during storage (continued)

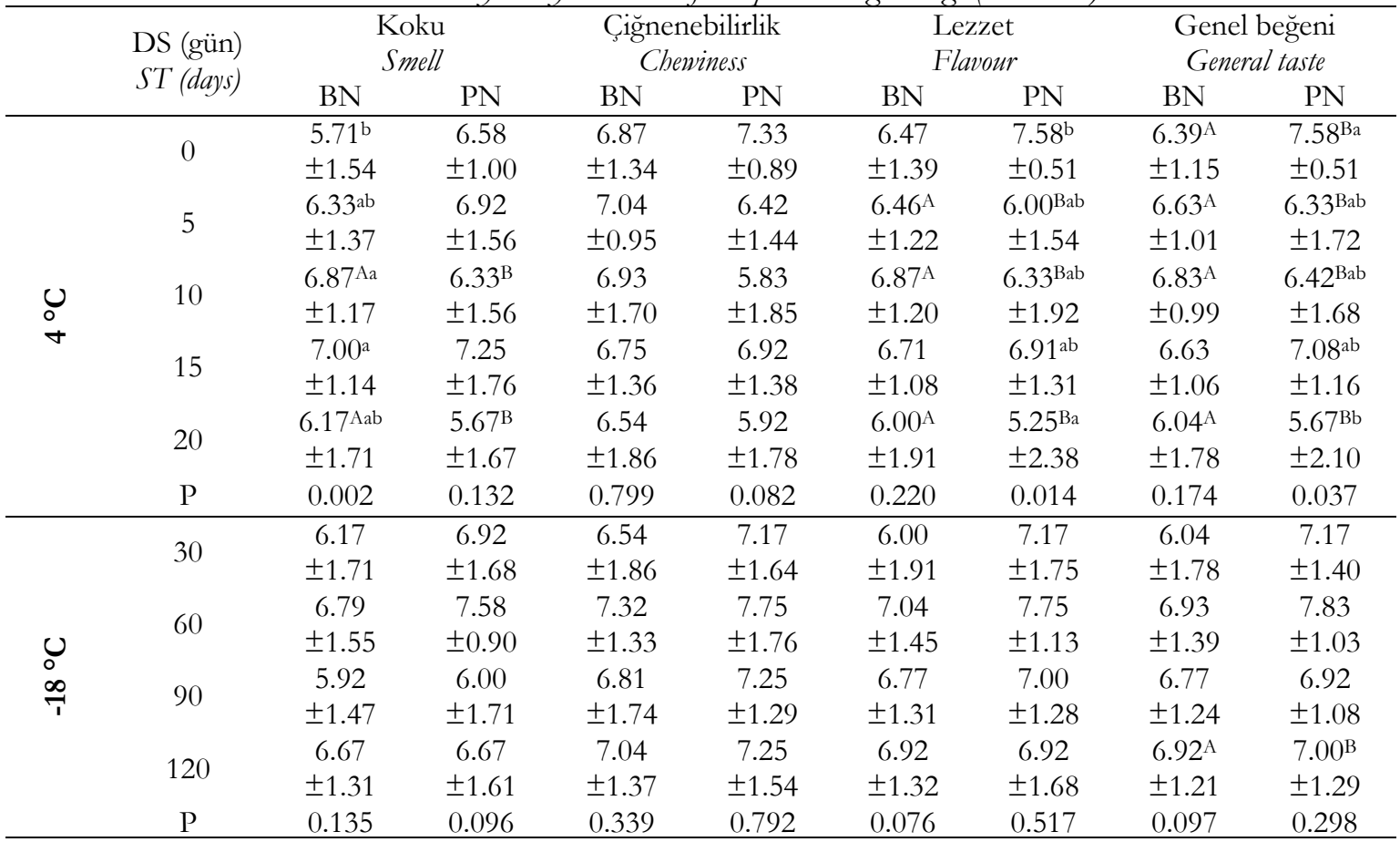

DS: Depolama süresi (gün); a, b. c: Aynı sütunda farklı harflerle gösterilen ortalamalar istatistik açıdan birbirinden farklidır $(P<0.05)$.

A, B: Aynı satırda farklı harflerle gösterilen ortalamalar istatistik açıdan birbirinden farklıdır $(P<0.05)$.

ST: Storage time (days); a, b. c: The averages of different letters in the same column are statistically different $(P<0.05)$.

$A, B$ : The averages shown in different letters on the same line are statistically different $(P<0.05)$.

\section{Mikrobiyolojik Analiz Bulguları}

TMAB ve TPAB sayıları nugget gibi pişirilmiş et ürünlerinde mikrobiyolojik kalitenin belirlenmesinde önemli kriterlerdir. İleri işleme sırasındaki kaplama işlemi bakteriyel bozulmayı yavaşlatmakta, kızartma ișlemi ise mikroorganizmaların gidalarda varlığını azaltmakta ve son olarak ön pişirme işlemi de raf ömrünü uzatmaktadır (Çankırılıgil ve Berik 2016). Depolama süresince $\mathrm{BN}$ ve $\mathrm{PN}$ örneklerine ait mikrobiyolojik analiz bulguları Çizelge 10 'da verilmiştir. Soğuk depolanan $\mathrm{BN}$ örneklerindeki en yüksek TMAB sayıs $5.70 \mathrm{log} \mathrm{kob} / \mathrm{g}$, TPAB say1s1 $6.40 \mathrm{log} \mathrm{kob} / \mathrm{g}$, toplam Enterobacteriaceae sayıs1 <1; PN örneklerinde ise TMAB say1s1 8.02 $\log \mathrm{kob} / \mathrm{g}$, TPAB sayıs1 $8.90 \mathrm{log} \mathrm{kob} / \mathrm{g}$ ve toplam Enterobacteriaceae sayis1 $5.12 \log \mathrm{kob} / \mathrm{g}$ olarak 20. günde gözlenmiştir. Donmuş depolamanın 120. gününde hem $\mathrm{BN}$ hem de $\mathrm{PN}$ örneklerinde TMAB, TPAB ve toplam Enterobacteriaceae sayis1 $<1$ olarak tespit edilmiştir. Salmonella spp. ve
Listeria monocytogenes ise her iki örnekte de tespit edilmemiştir. Benzer olarak Yavaş vd. (2008) piliç etinden üretilen kaplamalı ürünlerde raf ömrü boyunca meydana gelen değişimlerin incelendiği bir çalş̧mada kontrol grubu piliç nuggetlarda 21 günlük depolama boyunca en yüksek TMAB değerini $6.18 \mathrm{log} \mathrm{kob} / \mathrm{g}$ olarak 21. günde olduğunu tespit etmiştir.

\section{SONUÇ}

Çalısmada nugget üretimi ile hem yeni bir ürün üretilmiş hem de bıldırcın etinin değeri artırılmaya çalışılmıştır. BN örnekleri; soğuk depolamada $\mathrm{pH}$, SYA, su aktivitesi; duyusal özelliklerden iç renk ile mikrobiyolojik özelliklerden TMAB, TPAB, toplam Enterobacteriaceae, Salmonella ve Listeria varlığı açısından PN analiz sonuçları ile istatistik açıdan önemli olmayan farklılıklar göstermiştir. Donmuş depolamada ise, su aktivitesi, TBA ve peroksit değeri; enstrümantal renk değerlerinden Hunter $L^{*}, a^{*}$ ve $b^{*}$; duyusal özelliklerden iç renk, 
diş renk, sululuk, çiğnenebilirlik, koku ve lezzet analizi sonuçları açısından PN analiz sonuçları ile istatistik açıdan önemli olmayan farklılıklar göstermiştir. BN'nin PN ile benzer fizikokimyasal, tekstürel ve duyusal özellikler göstermesi, piyasaya sunulması durumunda, kabul edilebilirliği yüksek bir ürün olduğunu göstermektedir. Hatta BN'nin depolanmas1 boyunca acılaşma göstergesi olan peroksit ve TBA gibi değerlerinin PN'ye göre daha da düşük olması, duyusal analizde genel beğeni puanının PN'ye göre önemli düzeyde daha yüksek olması ve yine mikrobiyolojik analizlerde TMAB ve TPAB sayılarının PN'ye göre daha düşük kalması, ürünün tercih edilebilirliğinde önemli özellikler olarak görülmektedir. Bıldırcın etinin içerdiği besin öğelerinin sağlık faydaları da dikkate alındığında ileri işlenmiş ürünler gibi alternatif ürün seçeneklerinin piyasaya sunulması, bıldırcın etinin tüketimini artırmak adına yarar sağlayacaktır. Bu çalışma kanatlı eti üreticileri ve ileri işlenmiş et üreticileri için yeni bir ürün geliştirme açısından yol gösterici olacaktır. İleriki çalışmalarda hem bıldırcın nugget üretiminin hem de kaplama materyalinin formülasyonunda optimizasyon çalışmaları yapılarak ürün standardizasyonu sağlanabilecektir.

Çizelge 10. Örneklerin depolama boyunca mikrobiyolojik analiz bulguları Table 10. Results of microbiological analysis during storage

\begin{tabular}{|c|c|c|c|c|c|c|c|c|c|c|c|}
\hline & \multirow{2}{*}{ 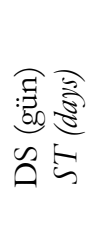 } & \multicolumn{2}{|c|}{$\begin{array}{c}\text { TMAB } \\
(\log \mathrm{kob} / \mathrm{g})\end{array}$} & \multicolumn{2}{|c|}{$\begin{array}{c}\text { TPAB } \\
(\log \mathrm{kob} / \mathrm{g})\end{array}$} & \multicolumn{2}{|c|}{$\begin{array}{c}\text { Toplam } \\
\text { Enterobacteriaceae } \\
(\log \mathrm{kob} / \mathrm{g})\end{array}$} & \multicolumn{2}{|c|}{$\begin{array}{c}\text { Salmonella spp. } \\
(\log \mathrm{kob} / 25 \\
\mathrm{g})\end{array}$} & \multicolumn{2}{|c|}{$\begin{array}{c}L . \\
\text { monocytogenes } \\
(\log \mathrm{kob} / 25 \\
\mathrm{g})\end{array}$} \\
\hline & & $\mathrm{BN}$ & $\mathrm{PN}$ & $\mathrm{BN}$ & PN & $\mathrm{BN}$ & PN & $\mathrm{BN}$ & PN & $\mathrm{BN}$ & PN \\
\hline \multirow{5}{*}{$\begin{array}{l}\text { U } \\
\text { v }\end{array}$} & 0 & $3.65 \pm 0.2$ & $2.34 \pm 0.2$ & $3.63 \pm 0.1$ & $2.09 \pm 0.6$ & $<1$ & $<1$ & Yok & Yok & Yok & Yok \\
\hline & 5 & $3.90 \pm 0.3$ & $3.63 \pm 0.3$ & $4.11 \pm 0.1$ & $3.71 \pm 0.4$ & $<1$ & $<1$ & Yok & Yok & Yok & Yok \\
\hline & 10 & $4.86 \pm 1.6$ & $4.70 \pm 0.2$ & $4.72 \pm 1.3$ & $6.97 \pm 0.1$ & $<1$ & $3.43 \pm 0.2$ & Yok & Yok & Yok & Yok \\
\hline & 15 & $5.10 \pm 1.4$ & $6.92 \pm 0.2$ & $5.30 \pm 1.1$ & $7.19 \pm 0.1$ & $<1$ & $4.51 \pm 0.1$ & Yok & Yok & Yok & Yok \\
\hline & 20 & $5.70 \pm 0.3$ & $8.02 \pm 0.2$ & $6.40 \pm 0.1$ & $8.90 \pm 0.1$ & $<1$ & $5.12 \pm 0.8$ & Yok & Yok & Yok & Yok \\
\hline \multirow{4}{*}{$\begin{array}{l}0 \\
0 \\
\infty \\
T\end{array}$} & 30 & $2.78 \pm 0.5$ & $3.15 \pm 0.2$ & $3.43 \pm 0.1$ & $<1$ & $<1$ & $<1$ & Yok & Yok & Yok & Yok \\
\hline & 60 & $2.62 \pm 0.2$ & $2.62 \pm 0.2$ & $2.73 \pm 0.3$ & $<1$ & $<1$ & $<1$ & Yok & Yok & Yok & Yok \\
\hline & 90 & $2.67 \pm 0.1$ & $2.87 \pm 0.1$ & $<1$ & $<1$ & $<1$ & $<1$ & Yok & Yok & Yok & Yok \\
\hline & 120 & $<1$ & $<1$ & $<1$ & $<1$ & $<1$ & $<1$ & Yok & Yok & Yok & Yok \\
\hline
\end{tabular}

DS: Depolama süresi (gün); $\mathrm{n}=3$; a, b. c: Aynı sütunda farklı harflerle gösterilen ortalamalar istatistik açıdan birbirinden farklıdır $(P<0.05)$.

A, B: Aynı satırda farklı harflerle gösterilen ortalamalar istatistik açıdan birbirinden farklıdır $(P<0.05)$.

ST: Storage time (days); $n=3 ; a, b$. c: The averages of different letters in the same column are statistically different $(P<0.05)$.

$A, B:$ The averages shown in different letters on the same line are statistically different $(P<0.05)$.

\section{TEŞEKKÜR}

Çalışmaya destek veren Bolu Abant İzzet Baysal Üniversitesi BAP Koordinatörlüğü'ne (Proje No: 2016.09.04.1030) ve Erpiliç Entegre Tavukçuluk Üretim Pazarlama ve Tic. Ltd. Şti.'ne teşekkür ederiz.

\section{KAYNAKLAR}

Akgün, A.A. (2006). Farklı Kaplama Formülasyonları ile Kaplanmış Tavuk
Köftelerinin Duyusal, Fiziksel, Kimyasal ve Mikrobiyolojik Özellikleri. Pamukkale Üniversitesi Fen Bilimleri Enstitüsü Gıda Mühendisliği Anabilim Dalı Yüksek Lisans Tezi, Denizli, Türkiye, $87 \mathrm{~s}$.

Anıl, N., Doğruer, Y., Gürbüz, U. (1995). Tavuk Etinin Beslenmedeki Yeri ve Önemi, VI. Hayvancilık ve Beslenme Sempozyumu, 23-25 Ekim 1995, Konya, Türkiye, 167-174 s. 
AOAC (1990). Official Methods of Analysis. Association of Official Analytical Chemists, IAC, Arlington, VA, USA.

AOCS (2003). Sampling and Analysis of Commercial Fats and Oils. AOCS Official Method Cd 8-53, Surplus Peroxide Value Acetic Acid-Chloroform Method. AOCS Cold Spring Harbour, NY, USA.

Aylangan, A., Vural, H. (2012). Farklı Işınlama Dozlarının Hamburger Köftelerinin Bazı Fiziksel, Kimyasal ve Duyusal Özellikleri Üzerine Etkileri. G1da, 37(1): 9-16.

Bayrak, E. (2011). Farklı Baharat Ekstraktlarının Mekanik Ayrılmış Piliç Etlerinden Üretilen Sosislerin Bazı Kalite Özellikleri Üzerine Etkisi. Selçuk Üniversitesi Fen Bilimleri Enstitüsü Doktora Tezi, Konya, Türkiye, 118 s.

Bligh, E.G., Dyer, W.J. (1959). A Rapid Method of Total Lipid Extraction and Purification. Can J Biochem Physiol, 37(8): 911-917.

Bostan, K., Uğur, M., Çetin, Ö. (2001). Bitkisel Yağ ve Lif Kullanılarak Kanatlı Eti Salamı Üretimi Üzerine Deneysel Çalışmalar. İstanbul Üniv Vet Fak Derg, 27(2): 645-657.

Boulianne, M., King, A.J. (1995). Biochemical and Color Characteristics of Skinless Boneless Pale Chicken Breast. Poult Sci, 74(10): 1693-1698.

Choudhary, C.K., Londhe, S.V., Patil, D.P., Gangane, G.R., Bhumre, P.N., Shinde P.A., Nemade, A.S. (2019). Evaluation of Shelf-life of Bengal Gram Flour Based Japanese Quail Meat Nuggets. Journal of Entomology and Zoology Studies, 7(3): 999-1003.

Çankır1lıgil, E.C, Berik, N (2016). Gökkuşağ1 Alabalığ1 (Oncorbynchus mykiss) Kroketlerinin Soğuk Muhafazada $\left(+4^{\circ} \mathrm{C}\right)$ Raf Ömrünün Belirlenmesi, Turkish J Aqua Sci, 32(1): 35-48.

Çelik, Ş., İnci, H., Kayaokay, A. (2014). Bıldırcınlarında Canlı Ağırlığın Yetiştirme Sistemleri ve Cinsiyete Göre İncelenmesi. TURKJANS, 1(3): 384-389.

Çolak, H., Uğurluay, G., Nazlı, B., Bingöl, E.B. (2011). Paketlemede Kullanılan Nem Tutucu
Filtrelerin Hindi Etinin Raf Ömrü Üzerine Etkisi. İstanbul Üniv Vet Fak Der, 37(2): 107-116.

Demirkaya, A. K. (2013). Tereyağında Tiyobarbiturik Asit (TBA) Testi ile Lipid Oksidasyonunun Değerlendirilmesi. Atatürk Üniversitesi Vet Bil Derg, 8(3): 237-240.

Demirkaya, A.K. (2014). Bilecik İlinde Tüketime Sunulan Kiyma ve Tavuk Etlerinde Lipid Oksidasyonu. Akademik G1da, 12(3): 26-29.

Ensoy, Ü. (2004). Hindi Sucuğu Üretiminde Starter Kültür Kullanımı ve Isıl İşlem Uygulamasının Ürün Karakteristikleri Üzerine Etkisi. Ankara Üniversitesi Fen Bilimleri Enstitüsü Gıda Mühendisliği Anabilim Dalı Doktora Tezi, Ankara, Türkiye, 147 s.

Ergezer, H. (2005). Değişik Yöntemlerle Marine Edilmiş Kanatlı Etlerin Kimyasal Mikrobiyolojik, Tekstürel ve Duyusal Özellikleri. Pamukkale Üniversitesi Fen Bilimleri Enstitüsü Gıda Mühendisliği Bölümü Yüksek Lisans Tezi, Denizli, Türkiye, $100 \mathrm{~s}$.

Ertaş, N., Doğruer, Y. (2010). Besinlerde Tekstür. Erciyes Üniv Vet Fak Derg, 7(1): 35-42.

Kaymak Erten, F. (2005). Gida Maddelerinin Kaplanması: Kaplama Yöntem ve Ekipmanları. Pamukkale Üniv Müh Bilim Derg, 11(1): 85-94.

Genchev, A., Mihaylova, G., Ribarski, S., Pavlov, A., Kabakchiev, M. (2008). Meat Quality and Composition in Japanese Quails. Trakia J of Sci, 66(4): 72-82.

Gökçe, R., Akgün, A.A., Ergezer, H., Akcan, T. (2016). Farklı Kaplama Bileşenleriyle Kaplamanın Derin Yağda Kızartılan Piliç Nuggetların Bazı Kalite Karakteristikleri Üzerine Etkileri. Tarım Bilimleri Dergisi, 22 (3): 331-338.

Gülüm, L., Akoğlu, İ.T., Akoğlu, A. (2016). Determination of Consumer Perception For Using Quail Meat in The Further Processed Products. International Congress on Food of Animal Origin (Industry Partnership), 10-13 November 2016, Turkish Republic of North Cyprus, 110-113 s.

Güner, K.G. (2005). Farklı Kaplama Materyali Kullanılarak Üretilen Tavuk Nuggetlerin Kalite 
Özelliklerinin Belirlenmesi Üzerine Bir Araştırma. Trakya Üniversitesi Fen Bilimleri Enstitüsü Gıda Mühendisliği Bölümü Yüksek Lisans Tezi, Edirne, Türkiye, $91 \mathrm{~s}$.

Halkman, A.K. (2005). Merck Guda Mikrobiyolojisi Uygulamaları. Başak Matbaacılık Ltd. Şti., Ankara, Türkiye, $358 \mathrm{~s}$.

Hunt, M., Acton, J., Benedict, R., Calkins, C., Cornfort, D., Jeremiah, L., Shivas, S. (1991). Guidelines For Meat Color Evaluation. National Live Stock and Meat Board Publisher Chicago, Illinois, $17 \mathrm{p}$.

ISO 11290-1 (1996). Microbiology of Food and Animal Feeding Stuffs Horizontal Method for the Detection and Enumeration of Listeria monocytogenes Part 1: Detection method. https://www.iso.org/standard/19268.html

(Erişim tarihi: 01.02.2018)

ISO 6579 (2002). Microbiology of Food and Animal Feeding Stuffs Horizontal Method for the Detection of Salmonella spp. https://www.iso.org/standard/29315.html (Erişim tarihi: 01.02.2018)

Jimenez, M., Garcia, H., Beristain, C. (2006). Spray-dried Encapsulation of Conjugated Linoleic Acid (CLA) with polymeric matrices. J Sci Food Agric, 86(14): 2431-2437.

Kolsarıc1, N., Candogan, K. (1995). The Effects Of Potassium Sorbate and Lactic Acid on The Shelf-Life of Vacuum-Packed Chicken Meats. Poult Sci, 74(11): 1884-93.

Kolsarıcı, N. (2004). Mekanik Ayrılmış Tavuk Etlerinin Soğuk ve Donmuş Depolama Stabilitesi. Ankara Üniversitesi, Bilimsel Araştırma Projesi Kesin Raporu, Ankara, 51 s.

Laçin, E., Çoban, Ö., Sabuncuoğlu, N. (2007). Japon Bildırcinlarında (Coturnix coturnix japonica) Farklı Işık Şiddeti ve Canlı Ağırllğın Bazı Performans Özellikleri Üzerine Etkileri. Atatürk Üniversitesi Vet Bil Derg, 2(1): 28-33.

Lukman, I., Nurul, H., Noryati, I. (2009). Physicochemical and Sensory Properties of Commercial Chicken Nuggets. As J Food Ag-Ind, 2(2): 171-180.
Maiorano, G., Knaga, S., Witkowski, A., Cianciullo, D., Bednarczyk, M. (2011). Cholesterol Content and İntramuscular Collagen Properties of Pectoralis Superficialis Muscle of Quail From Different Genetic Groups. Poult Sci, 90(7): 1620-1626.

Nasar, A., Rahman, A., Hoque, N., Talukder, A.K., Das, Z.C. (2016). A Survey of Japanese Quail (Coturnix Coturnix japonica) Farming in Selected Areas of Bangladesh. Vet World, 9(9): 940.

Nazlıül, A., Bardakçıŏlu, H.E .(2001). Japon B1ldircinlarında (Coturnix coturnix japonica) Yerleşim Siklı̆ıııı Yumurta Verimi, Yumurta Ağıllığ ve Yem Tüketimine Etkisi. İstanbul Üniv Vet Fak Derg, 27(2): 429-438.

Rinaldi, M., Dall'Asta, C., Paciulli, M., Cirlini, M., Manzi, C., Chiavaro, E. (2014). A Novel Time/Temperature Approach to Sous Vide Cooking of Beef Muscle. Food Bioprocess Tech, 7(10): 2969-2977.

Sarıca, M., Camcı, Ö., Selçuk, E. (2003). Bıldırcın, Sülün, Keklik, Etçi Güvercin, Beç Tavuğu ve Devekuşu Yetiştiriciliği, 3. Baskı, Ondokuz Mayıs Üniversitesi Ziraat Fakültesi Bask1 Ünitesi, Samsun.

Şekeroğlu, A., Eleroğlu, H., Sarıca, M., Camcı, Ö. (2013). Yerde Üretimde Kullanilan Altlık Materyalleri ve Altlı Yönetimi. Tavukçuluk Araştırma Dergisi, 10: 25-34.

Tarladgis, B.G., Watts, B.M., Younathan, M.T., Dugan, L. (1960). A Distillation Method For The Quantitative Determination of Malonaldehyde in Rancid Foods. J Am Oil Chem Soc, 37(1): 44-48.

Yavaş, E., Bilgin, B., Yılmaz, İ. (2008). Piliç Etinden Üretilen Kaplamalı Ürünlerde Raf Ömrü Boyunca Meydana Gelen Değişimler. Türkiye 10. Gida Kongresi, 21-23 May1s 2008, Erzurum, Türkiye, 577-580 s.

Yıldırım, A., Öztürk, E. (2013). Damızlık Japon Bıldırcını Rasyonlarında Soya Küspesi Yerine Pamuk Tohumu Küspesi İkamesinin Yumurta Verim ve Kalite Özelliklerine Etkisi. TURJAF, 1(1): 44-50. 